\title{
SENDER'S SELF-MONITORING TRAITS: CONDUCIVE FACTORS AFFECTING INTERPERSONAL COMMUNICATION AMONG TURKISH UNIVERSITY STUDENTS
}

\author{
Cem Sefa Sütcü ${ }^{1}$, \\ And Algül' \\ N. Hanzade Uralman ${ }^{3}$
}

\begin{abstract}
Self-monitoring researches show that high self-monitoring individuals have not only ability to selfdisclosure but also have ability to facilitate others' disclosure. The aim of this paper is to define this conducive factors understanding which communication skills of university students in Turkey facilitate others' disclosure and create dialogic communication. In this study, 24 questions have been directed at participants, in order to make a determination in relation to the conducive skills of university students in Turkey, which allow a dialogue environment to be created during the process of interpersonal communication $(\mathrm{N}=384)$. As a result, it has been put forward which of the conducive skills that point out to a dialogue tendency are given importance.

Keywords; Interpersonal Communication, self-Monitoring, active listening, face to face communication, message design.

\section{ILETiŞiMDE KAYNAĞIN ÖZ-IZLENIMCiLiK NITELIKLERI:}

\section{TÜRKIYE'DEKI ÜNIVERSITE GENÇLiĞiNIN KişiLERARASI ILETişiMiNi ETKILEYEN UNSURLAR \\ ÖZET}

Öz-izlenimcilik ile ilgili araştırmalar, öz-izlenimcilik becerisi yüksek bireylerin sadece kendilerini ifade etme özelliğine sahip olmadıklarını, aynı zamanda başkalarının da kendilerini ifade etmelerini kolaylaştırdıklarını ortaya koymaktadır. Bu çalışmanın amacı, Türkiye'de üniversite öğrencilerinin hangi iletişim becerilerinin, iletişim kurmaya yönelik, insanların kendilerini ifade etmesini kolaylaştırdığını ve diyaloga dayalı bir iletişim ortamın oluşmasını sağladığını ortaya koymaktır. Anket yönteminin uygulandığı çalışmada öğrencilere, onların kişilerarası iletişimde diyalog ortamının oluşmasını kolaylaştıran öz-izlenimciliğe dayalı becerilerini anlamak üzere 24 soru yöneltilmiştir $(\mathrm{N}=384)$. Araştırmanın sonucu, Türkiye'deki üniversite öğrencilerinin diyalog ortamının kurulmasına önem verdiklerini gösteren eğilimlerinin olduğunu ortaya koymaktadır.
\end{abstract}

Anahtar Kelimeler: Kişilerarası iletişim, öz-izlenimcilik, aktif dinleme, yüz yüze iletişim, mesaj tasarımı

\footnotetext{
${ }^{1}$ Prof. Dr., Department of Informatics, Marmara University, TURKEY cemsutcu@ yahoo.com

${ }^{2}$ Assist. Prof. Dr., Department of Visual Communication Design, Istanbul Aydin University, TURKEY algul_a@yahoo.com

${ }^{3}$ Dr., Media and Communication Management MA Program, Yeditepe University, TURKEY huralman@gmail.com
} 


\section{Introduction}

Interpersonal communication skills allow an individual to effectively interact with other individuals. These skills make an individual's interaction with his environment possible and results from certain human needs. While interpersonal relationships allow individual development and contribute to communities to become groups, it is considered to be among basic human needs such as belonging, etc. (Baumeister \& Leary, 1995; Hullman, 2004: 212; Wood, 2011: 10).

Communication theoreticians state the importance of studying the dynamic nature of communication which individuals form with one another in daily social relationships (Step \& Finucane, 2002: 93). In interpersonal communication, the participation of individuals in the same level of communication creates dialogue, which is a type of communication. Dialogue is a type of communication, which allows people to understand one another. While a message is sent from its source to the receiver and continues without the feedback of the receiver, it transforms into dialogue when there is feedback as well (Tufte \& Metapulos, 2007: 13). This is the most basic characteristic which distinguishes monologue as the one-sided communication from dialogue. The speakers or listeners behave, attempting to avoid selfish, manipulative tendencies in dialogue (Floyd, 2010: 170).

In the creation of dialogue, since it is important how sensitive the speaker is to the listener's attitude and behaviors, the self-monitoring concept, which emphasizes that individuals should develop their skills in this aspect, should be dealt with. Self-monitoring is basically the ability to be sensitive to others' emotions and behaviors; to understand environmental contexts, and to modify self-presentation in response to these changing situations (Lennox \& Wolfe, 1984).

Synder who developed the term of self-monitoring in the 1970s, identifies it as an ability to manage one's self-presentation by controlling expressive behavior in response to environmental information (Soibel et al., 2012: 193). This definition shows that the self-monitoring concept does not only mean the speaker taking into consideration the listener and that, the speaker develops behaviors suitable to the conditions he is in as well. According to Shaffer and Pegalis, in Synder's studies, 
individuals are affected by their self-monitoring attitudes in interpersonal communication (Shaffer \& Pegalis, 1998: 216).

Speakers' level of self-monitoring (high or low) influences the communication process. Speakers are stimulus persons whose fixed characteristics (e.g, age, gender, and physical features) provide information (Nakamura, Buck \& Kenny, 1990: 1032). In the context of self-monitoring literature, individuals who are a part of the communication process can be analyzed within the context of disclosure or conducive. Conducive context is related to the speaker's self-monitoring ability. Self-monitoring speakers do not only display disclosure, they also give opportunity to the speaker for self-disclosure with their attitudes and behaviors. This conducive context is considered in interpersonal communication researches by Shaffer and Pegalis (1998: 218) to test the proposition that high self-monitoring individuals will be more effective than low self-monitoring individuals at inducing others to open up and reveal personal information about themselves in contexts that are most conducive to such self-disclosure.

Thus, distinctive trait of self-monitoring people is not only controlling their expressive behavior, self-presentation and non-verbal display of affection, but they consider with whom they communicate adopting themselves in changing situations. Likewise Schutte et al. (2001: 524) points out the skills of self-monitoring are empathy, the ability to self-monitor in social situations, good social skills, and cooperation. Thus, self-monitoring senders carry the potential to create a dialogic communication, which is one of the main types of communication along with monologue. Since self-monitoring individuals facilitate self-presentation and participation of other people to the communication process, it is possible to indicate that self-monitoring individuals have the attitude towards dialogic communication. In fact, according to results of their research (Shaffer \& Pegalis, 1998: 215) high selfmonitoring individuals are closer to dialogic communication.

Self-monitoring can be measured and occurs in different types of communication processes. These types can be seen in the figure 1 as verbal communication, non-verbal communication, group communication and two-way communication. The self-monitoring abilities of senders which facilitate two-way 
communication activating the receiver are determined as active listening, message design and face to face communication. These behaviors can also be defined as selfmonitoring traits in conducive context. The aim of this study is to define this conducive factors understanding which communication skills of university students in Turkey facilitate others' disclosure and create dialogic communication. The aim of previous studies on communication skills of university students in Turkey were to find out whether demographic factors such as gender, education level and age are effective or not. While some studies conducted on the communication skills of university students in Turkey show that the communication skills of female students are higher in comparison to male students (Toy, 2007: 67; Yilmaz et al., 2011: 968; Erigüç \& Eriş, 2013: 241-242), another study on the communication skills of university students has shown that gender does not have a relation with communication skills (Erözkan, 2007: 67-68). This research provide a percpective on communication skills of Turkish students using conducive context.

\section{Literature Review: Self-monitoring Communication Skills in Conducive Context}

Synder developed a scale to measure people's self-monitoring ability and this scale is re-developed by Lennox and Wolfe (1984). A number of different existing self-monitoring measurements which are still being actively employed in researches (Soibel et al., 2012: 194), consider these abilities of individuals (Lennox \& Wolfe, 1984: 1349-1350). These scales which measure self-monitoring abilities are convenient in understanding individuals' roles in interpersonal communication. The questions in these scales are principally based on understanding people's attitudes and behaviors in interpersonal relationships.

Literature research points out that, there are various skills which are verbal and non-verbal, that allow the self-monitoring levels of individuals to be high. All behaviors provide an impression about a speaker on listeners. Self-monitoring individuals can exercise their expressive behavior, self-presentation, and non-verbal display of affection (Snyder, 1979: 86) using these skills and control their selfimpression. Many of the judgments we make about others are based on cues from 
expressive behaviors, such as facial expressions, posture, speech, body movement etc. (Ambady \& Rosenthal, 1992: 256; Nakamura, Buck \& Kenny, 1990: 1033).

Self-presentation which is indicated as another important trait of selfmonitoring people is the individuals' efforts to create impression about themselves on others. Self-presentational behaviors can be separated into different types (Schütz, 1998: 173-178) including both verbal and non-verbal behaviors. In addition, it is recognized that self-presentation is significant in expressive behaviors (DePaulo, 1992: 203). Self-presentation is affected by the condition individuals are in. "The evidence for the validity of the self-monitoring construct suggests that high selfmonitoring individuals have all the requisite skills to successfully mold and tailor their self-presentation their situations" (Snyder, 1979: 93).

Self-presentation may be more effective with emotional intelligence. Emotional intelligence is another term which is important in understanding the term self-monitoring. "Because emotional intelligence encompasses understanding others' emotions and regulating one's own emotions (which may allow more effective selfpresentation), higher emotional intelligence may facilitate self-monitoring" (Schutte et al., 1998: 525).

Studies which analyze the relationship between communication skills and emotional intelligence have been realized in Turkey. One of these studies points out that there is a relationship between the communication skills of the participants and their emotional intelligence (Gürşimşek, Vural \& Demirsöz, 2008: 9). Another study shows that, there is a significant relationship between the communication skills of teacher candidates and their empathy (Küçük, 2011: 935).

The skill of designing messages is a verbal communication skill, which allows expressive behavior and self-presentation behavior of individuals to be displayed in a self-monitoring manner. High self-monitoring individuals produce rhetorical messages, because "rhetorical messages reflect a person's awareness and ability to address his or her own goals and the receiver's goals simultaneously" (Hullman, 2004: 210). The individuals' purposes in establishing communication, their closeness with the individuals they establish communication with are effective 
in their usage of message designing skill. Hullman, who studied message designing and interpersonal communication motivations, states that message designing which involves situations such as giving less importance to goal unity, being aware of their roles and obligations towards each other, control, affection, inclusion, information seeking, etc. in friendships, do not form effective and appropriate interpersonal communication motivations within the scope of friendship relations (Hullman, 2004: 222).

Non-verbal display of affection as another fundamental aspect of selfmonitoring occurs during the communication process. There are many types of nonverbal communication, including paralinguistics (e.g., vocal features such as loudness, pitch, rate, and hesitations), kinesics (e.g., gestures, facial expressions, and body postures), haptics (e.g., touch, such as a handshake, a pat on the back and placing an arm around the shoulder), chronemics (e.g., time, such as making people wait), iconics (e.g., physical objects, such as the size of a desk or a display of trophies), proxemics (e.g., personal space), and dress (e.g., clothing and physical appearance) (Stevens \& Campion, 1994: 513). Non-verbal behaviors which individuals form by taking each other into consideration during the communication process originate from self-monitoring. In line with the conducive skill of the speaker, it is possible for dialogue to be initiated as a result of the speaker's encouraging behavior towards the listener to speak.

Skills which allow individuals to form dialogic communication are regarded as important in therapy oriented communication as well (Bhana, 2014: 1-5). In areas such as marriages which require therapy oriented communication, crisis consultancy, education, this kind of communication is needed. The skill of active listening is one of the therapeutic communication skills. Active listening is the display of the listener that he accepts the experience of the speaker unconditionally and objectively and is defined as the listener understanding the speaker without adding his own interpretation (Weger et al., 2010: 35; Stevens \& Campion, 1994: 513). "Selfdisclosure, trust, communication, expression of feelings and helpful listening and responding, as some of the interpersonal skills that can be developed further in order to establish and maintain therapeutic relationships" (Bhana, 2014: 2). Weger et al. 
have determined that as a result of researching literature which involve therapeutic communication that, there are verbal and non-verbal communication skills which make active listening possible. These are non-verbal involvement to conversation, paraphrasing the speaker's speech, asking questions to the speaker to elaborate his/her own beliefs or feelings (Weger et al., 2010: 35). These skills which make therapeutic communication possible are important in terms of dialogic communication, since they encourage the listener to speak. At this point, it is seen that these encouraging behaviors result from the feedback given by the listener to the speaker. It is stated that, feedback constantly affects the interaction between two individuals (Koprowska, 2010: 5-18).

Individuals' harmony with the social environment and the situations they are in while establishing communication with others is regarded as another important aspect in terms of the testing of their self-monitoring skills. While individuals whose self-monitoring is high evaluate the social situations they are in more carefully, individuals whose self-monitoring is low pay less attention to them (Snyder, 1979: 93-94). For instance, it is seen that individuals display active listening behavior which is regarded as important in terms of self-monitoring in order to be socially attractive. The results of the study conducted by Weger et al., (2010: 34) show that "message paraphrasing was associated with the social attractiveness of the listener, but was not associated with participants' conversational satisfaction or perceptions of feeling understood by the listener". Being affected by social attractiveness, selfmonitoring points out to the importance of group communication and the selfpresentation of the individual within this communication. In fact, Snyder states that individuals are able to create a positive impression through verbal and non-verbal behaviors in relation to themselves under all circumstances and talk about the selfpresentation skills within the social environment (Snyder, 1979: 94). For instance, Larsen and Hill (1958: 505) state that statues which are a manner of individuals' expressing themselves within a group affects interpersonal interaction. 


\section{Research Method and Findings}

The purpose of this research is to determine what the self-monitoring based communication skills are, which allow dialogue to be established between individuals, in terms of university students in Turkey. Accordingly the research question of this study; what are the attitudes which allow university students in Turkey to have dialogue? In the light of the review above, the hypothesis is built up as, "University students in Turkey are aware of having self-monitoring skills". To test this hypothesis, a survey has been realized with 384 participants selected thorough the random sampling method, on 2012. The survey study consists of a total of 38 questions, 24 of which are about understanding communication skills and 14 of which are demographic.

As a result of the reliability test, when all of the questions were analyzed, Cronbach's Alpha value was determined to be 0.769 . In order to increase reliability, it was considered necessary to exclude 8 questions from the survey. In the analysis made accordingly, Cronbach's Alpha value was determined to be 0.839. The Alpha value obtained shows that the study is reliable enough.

In the study, within the scope of verbal communication, non-verbal communication, group communication and two-sided communication types to determine communication skills, individuals' interpersonal communication skills have been taken into consideration and a total of 24 questions have been directed at the participants. The questions have been prepared to evaluate the speaker's skills of encouraging dialogue by motivating the listener to speak in interpersonal communication.

The KMO values show that the study is suitable for factor analysis. KMO Measure of Sampling Adequacy has been determined to be 0.882. Barlett's Test of Sphericity Approx. Chi-Square value have been determined to be 1363,036 and $\mathrm{p}=0.000$.

As a result of the literature research, verbal communication skills, non-verbal communication skills, group communication skills and two-sided communication skills of individuals have been determined as conducive factors which are regarded 
as effective by individuals in terms of being inclined to dialogue. On the other hand, in this study conducted on university students in Turkey, the conclusion that these factors are transitional between themselves and the factors regarded as effective in the attitude towards dialogue are collected under the following headings:

1. Active listening effect factor,

2. Message designing factor,

3. Face to face communication factor.

In the study conducted, $52.1 \%$ of the participants are female and $47.4 \%$ are male. $67.1 \%$ of the participants are between 20 and 24 years of age. $72.1 \%$ are from a foundation university and $20.6 \%$ are from a state university. $61.5 \%$ of the participants who answered the question on the department they receive their education in are from the social department and $31.8 \%$ are from the science department. $17.2 \%$ of the participants stated that they work full-time and the rest of the participants stated that they either work part-time or do not work at all. $90.9 \%$ of the participants are single. $38.5 \%$ have a family income of over 4000 TL. $76.8 \%$ stated that their parents are together as their family status. 52.9\% stated that they have a sibling. $77.3 \%$ are university students. $57 \%$ live with their families. $71.2 \%$ spend less than 1500 TL monthly. 79.2\% spend time on the Internet for more than an hour a day. $30.8 \%$ stated that they spend more than 4 hours on the Internet every day.

In the survey, since ordinal scale measurement was used, Kruskal-Walllis H $(\mathrm{K}-\mathrm{W})$, Spearman rho and Mann-Whitney $\mathrm{U}(\mathrm{M}-\mathrm{W})$ tests have been used in the hypothesis tests and non-parametric tests. As a result of the study, data in relation to the attitude toward communication skills based on self-monitoring, which allow the establishment of dialogue in the communication between individuals in Turkey.

One of these results is that, there is a positive relationship between "active listening" and "message designing" (rho=0.406, $\mathrm{p}=0.000$ ). As "active listening" increases, "message designing" increases as well. Those who gave positive answers in terms of "active listening" have also given positive answers in terms of "message designing". According to this, besides accepting the experiences of the person they listen to unconditionally and objectively, individuals produce rhetorical messages 
themselves as well. The direct proportion between these two point out to the attitudes of individuals towards communication skills based on self-monitoring, which allow dialogue to be created. Perhaps, one of the reasons is that, the researched community is from the Y-generation. This is also supported by the direct proportion determined between "face to face communication" and "active listening". There is a positive relationship between "face to face communication" and "active listening" (rho=0.450, $\mathrm{p}=0.000)$. It has been observed that, participants who answered positively in relation to "face to face communication" also answered positively in relation to "active listening". The individuals giving importance to face to face communication shows that they have a self-monitoring attitudes during the communication process by giving importance to verbal and non-verbal behavior. The positive relationship between "message designing" and "face to face communication" ( $(\mathrm{ho}=0.385, \mathrm{p}=0.000)$ is a data related to the attitudes of individuals who are university students in Turkey towards self-monitoring.

$68.2 \%$ of the participants stated that they can gather their ideas into a message while communicating. This puts forward the skill of message designing. $81.3 \%$ of the participants giving importance to the expectations of those who listen to them are an important data related to the fact that individuals in Turkey give importance to the listener while communicating and produce messages in this respect.

$57.3 \%$ of the participants definitely giving the information the other party needs to be transparent during communication are a data related to message designing. $29.2 \%$ being indecisive and $13.5 \%$ giving negative answers shows that individuals do not give importance to being transparent and that, there are problems related to being transparent and transmitting information. On the other hand, it has been observed that a majority of the individuals who participated in the survey give importance to having information and ideas in order to design messages. $65.4 \%$ of the participants stated that they do not speak if they do not have an idea about the subject being talked about within the group and that they remain silent. $21.1 \%$ stated that they are indecisive.

While the individuals' preference for face to face communication shows selfmonitoring attitudes, the Internet usage frequency affects this attitudes negatively. A 
communication skill based on self-monitoring, active listening decreases as Internet usage frequency increases. This is also understood from the negative relationship between "active listening" and "Internet usage frequency" (rho $=-0.110, \mathrm{p}=0.034)$.

There is a positive relationship between "Internet usage frequency" and education level (rho=0.087, $\mathrm{p}=0.092$ ), monthly expense amount (rho=0.251, $\mathrm{p}=0.000$ ), monthly family income ( $\mathrm{rho}=0.108, \mathrm{p}=0.042$ ). As education level, monthly expense amount and monthly family income increase, internet usage frequency increases as well. In addition, the positive relationship between monthly expense amount and monthly family income $(\mathrm{rho}=0.495, \mathrm{p}=0.000)$ and the positive relationship between education level and monthly expense amount (rho=0.227, $\mathrm{p}=0.000$ ) shows that Internet usage causes a digital divide in terms of educated users who have a high income level. If it is taken into consideration that "Internet usage frequency" decreases the communication skills based on self-monitoring, they display less of behaviors which support the communication process of the listener, when educated individuals of high income who use information technology more take the listener less into consideration while communicating.

In Turkey, the self-monitoring levels may be related to the individuals' sibling condition as well; because within the scope of the study, a negative relationship has been determined between "Internet usage frequency" which affects the individuals" self-monitoring levels and sibling condition (rho $=-0.115, \mathrm{p}=0.027$ ). According to this, the negative relationship between "Internet usage frequency" and sibling condition, that is, the decrease in Internet usage frequency as the number of siblings increase, also displays a social reality. In addition, there is a negative relationship between monthly expense amount and sibling condition (rho $=-0.204$, $\mathrm{p}=0.000$ ). This negative relation verifies the negative relationship between Internet usage frequency and sibling condition as well.

A difference has not been determined between the genders of the participants in terms of face to face communication, where the individuals display their verbal and non-verbal communication skills $(\mathrm{M}-\mathrm{W}$ U value $=16.780, \mathrm{p}=0.175) .64 .8 \%$ of the participants stated that they give importance to using verbal or non-verbal communication methods suitable for the person they are communicating with in their 
communications with other people. However, it has been determined that women gave more positive answers to "active listening" which is a conducive factor, in comparison to men $(\mathrm{M}-\mathrm{W} \mathrm{U}$ value $=14.819, \mathrm{p}=0.001)$. In addition to this, it has been observed that women gave more positive answers to "message designing" which is also a conducive factor, in comparison to men $(\mathrm{M}-\mathrm{W} \mathrm{U}$ value $=15.928, \mathrm{p}=0.024)$.

Individuals' family environments in which they are raised up in is also important in terms of their dialogue forming skills. The result of the study has shown that, there is a significant difference between the participants' family condition, in terms of "message designing" and "face to face communication" among the conducive factors. In terms of family condition, while those who are with their parents have more positive views on message designing in comparison to those whose mothers or fathers have been married more than once, separated and deceased, the group whose mothers or fathers have been married more than once have the most negative views (K-W Chi-square $=12.494, \mathrm{p}=0.006$ ). In terms of family condition, while those whose mothers or fathers are deceased have the most positive views on face to face communication in comparison to other groups, the group whose mothers or fathers have been married more than once have the most negative views $(\mathrm{K}-\mathrm{W}$ Chi-square=9.601, $\mathrm{p}=0.022$ ).

\section{Conclusion}

The findings of the research verify the hypothesis that university students in Turkey are aware of having self-monitoring skills. The attitudes which allow university students in Turkey to have dialogue were figured out in the study. It has been observed that active listening, message designing and face to face communication skills, which are among the conducive skills that affect the creation of dialogue, are given importance to by the participants. As a result of the literature research and these conducive skills being defined in particular as necessary skills in the creation of dialogue, it has been seen that a majority of university students in Turkey have differences in establishing dialogue. However, certain results of the study show that skills which are used to establish dialogue are given importance to 
due to creating an impression in the environment, rather than being used to exchange information. Today, where circulation of information is important, individuals' forming their images in a positive direction in interpersonal relationships comes to the fore. It may be suggested that, this is the effect of communication via electronic means.

For instance, individuals preferring not to speak when they do not have an idea on the subject which is discussed, or hesitating to speak; individuals who do not have a definite idea on message designing not giving importance to message designing prefer stating their existing knowledge and ideas, rather than forming rhetorical messages directed at receiving information or having opinions. This brings to the mind the question of whether the individuals' establishing communication with other individuals takes place with the purpose of creating images or not.

In Turkey, individuals who are university students give less importance to message designing in comparison to active listening skill. However, self-monitoring individuals express that, they have the skill of designing messages besides taking the listener into consideration. Giving importance only to the expectations of the listener remains insufficient in terms of dialogue. At this point, the expressive behaviors and self-presentation of individuals remain insufficient in terms of verbal communication.

Even though the study results show that self-monitoring skills directed at forming dialogues are important, it should be noted that the number of the answers saying "I agree" are higher than the answers saying "I completely agree". Therefore the participants have not completely agreed with the study result.

Another important result arising within the scope of the study is that, as Internet usage increases, active listening decreases. This verifies certain criticisms directed at Internet addiction. 


\section{REFERENCES}

AMBADY, Nalini \& ROSENTHAL, Robert (1992). "Thin Slices of Expressive Behavior as Predictors of Interpersonal Consequences: A Meta-Analysis", Psychological Bulletin, 111(2), 256-274.

BAUMEISTER, Roy F. \& LEARY, Mark R. (1995). "The Need to Belong: Desire for Interpersonal Attachments as a Fundamental Human Motivation", Psychological Bulletin, 117(3), 497-529.

BHANA, Varshika M. (2014). "Interpersonal Skills Development in Generation Y Student Nurses: A Literature Review", Nurse Education Today, 1-5. dx.doi.org/10.1016/j.nedt.2014.05.002.

DePAULO, Bella M. (1992). "Non-Verbal Behavior and Self-Presentation", Psychological Bulletin, 111(2), 203-243.

ERİGÜÇ, Gülsün \& ERİŞ, Hüseyin (2013). "Communication Skills of Students at Vocational Health High School: Harran University Sample”, Electronic Journal of Social Science, Summer 2013, 12(46), 232-254.

ERÖZKAN, Atılgan (2007). “Üniversite Öğrencilerinin İletişim Becerilerini Etkileyen Faktörler”, Eğitim Bilimleri Dergisi, 26(26), 59-72.

FLOYD, James (2010). "Provocation: Dialogic Listening as Reachable Goal", The International Journal of Listening, 24(3), 170-173.

GÜRŞİMŞEK, Işık; VURAL, Deniz Ekinci \& DEMİRSÖZ, Ebru Selçioğlu (2008). "Öğretmen Adaylarının Duygusal Zekaları ile İletişim Becerileri Arasındaki İlişki”, Mehmet Akif Ersoy Üniversitesi Eğitim Fakültesi Dergisi, 16, 1-11.

HULlMAN, Gwen A. (2004). "Interpersonal Communication Motives and Message Design Logic: Exploring Their Interaction on Perceptions of Competence", Communication Monographs, 71(2), 208-225.

KOPROWSKA, Juliet (2010). Communication and Interpersonal Skills in Social Work (Transforming Social Work Practice Series, Third Edition, Learning Matters.

KÜÇÜK, Duygu Piji (2011). "Müzik Öğretmeni Adaylarının Empatik Eğilimleri ile İletişim Becerileri Arasındaki İlişkinin İncelenmesi”, 2nd International Conference on New Trends in Education and Their Implications, Ankara: Siyasal Kitabevi, 935-942. 
LARSEN, Otto N. \& HILL, Richard J. (1958). "Social Structure and Interpersonal Communication", American Journal of Sociology, 63(5), 497-505.

LENNOX, Richard D. \& WOLFE, Raymond N. (1984). "Revision of the SelfMonitoring Scale", Journal of Personality and Social Psychology, 46(6), 1349-1364.

NAKAMURA, Makoto; BUCK, Ross \& KENNY, David A. (1990). "Relative Contributions of Expressive Behavior and Contextual Information to the Judgment of the Emotional State of Another", Journal of Personality and Social Psychology, 59(5), 1032-1039.

SCHUTTE, Nicola S.; MALOUFF, John M.; HALL, Lena E.; HAGGERTY, Donald J.; COOPER, Joan T.; GOLDEN, Charles J. \& DORNHEIM, Liane (1998). "Development and Validation of a Measure of Emotional Intelligence", Personality and Individual Differences, 25, 167-177.

SCHÜTZ, Astrid (1998). “Audience Perceptions of Politicians' Self-Presentational Behaviors Concerning Their Own Abilities", Journal of Social Psychology, 138(2), 173-188.

SHAFFER, David R. \& PEGALIS, Linda J. (1998). "Gender and Situational Context Moderate the Relationship between Self-Monitoring and Induction of SelfDisclosure”, Journal of Personality, 66(2), 215-234.

SNYDER, Mark (1979). "Self-monitoring Processes", In Leonard Berkowitz (Eds.), Advances in Experimental Social Psychology, New York: Academic Press, $12,85-128$.

SOIBEL, Alexander; FONG, Katrina; MULLIN, Justin B; JENKINS, Gwen \& MAR, Raymond A. (2012). "Is Self-Monitoring Related to Social Comparison? It Depends How You Ask”, Individual Differences Research, 10(4), 193-201.

STEP, Mary M. \& FINUCANE, Margaret O. (2002). "Interpersonal Communication Motives in Everyday Interactions", Communication Quarterly, 50(1), 93-109.

STEVENS, Michael J. \& CAMPION, Michael A. (1994). "The Knowledge, Skill, and Ability Requirements for Teamwork: Implications for Human Resource Management”, Journal of Management, 20(2), 503-530. 
TOY, Sevgi (2007). Mühendislik ve Hukuk Fakülteleri Öğrencilerinin İletişim Becerileri Açısından Karşılaştırılması ve İletişim Becerileriyle Bazı Değişkenler Arasındaki İlişki, Ankara University, Institute of Social Sciences, Department of Psychology, MA Thesis, Ankara.

TUFTE, Thomas \& MEFALOPULOS, Paolo (2007). Participatory Communication: A Practical Guide. Washington D.C.: The World Bank.

WEGER, Harry Jr.; CASTLE, Gina R. \& EMMETT, Melissa C. (2010). “Active Listening in Peer Interviews: The Influence of Message Paraphrasing on Perceptions of Listening Skill", The International Journal of Listening, 24, 34-39.

WOOD, Julia T. (2011). Interpersonal Communication: Everyday Encounters. USA, Wadsworth Cengage Learning.

YİLMAZ, Muge; KUMCAGIZ, Hatice; BALCİ-CELIKK, Seher \& EREN, Zerrin (2011). "Investigating Communication Skill of University Students with Respect to Early Maladaptive Schemas”, Procedia-Social and Behavioral Sciences, 30, $968-972$.

\section{APPENDIX}

Figure 1: The place of self-monitoring behaviors in communication types.

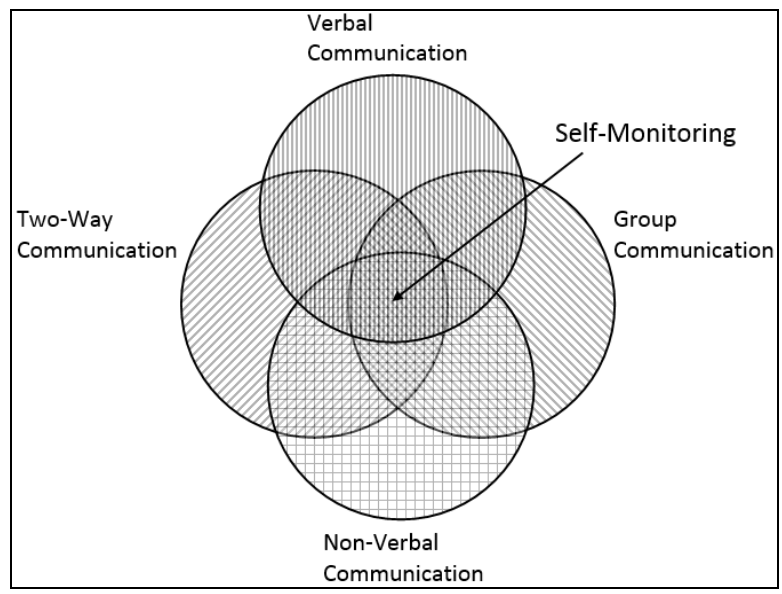

